\title{
Multi-objective optimization of a steady-state rotary dryer
}

\author{
Benjamín Barán \\ Universidad Comunera, Universidad Nacional de \\ Asunción, Asunción, Paraguay, \\ bbaran@pol.una.py \\ and \\ César Oviedo \\ Universidad Nacional de Asunción, Facultad de Ciencias \\ Químicas, San Lorenzo, Paraguay, \\ coviedo@qui.una.py \\ and \\ Michel Galeano \\ Universidad Nacional de Asunción, Facultad de Ciencias \\ Químicas, San Lorenzo, Paraguay, \\ michelosvaldo@qui.una.py
}

\begin{abstract}
The multi-objective optimization of a direct current rotary dryer that operates with pozzolana in a Paraguayan company is detailed in this article. For the first time, three objective functions in steady state are simultaneously minimized using a specialized variant of the well-known NSGA-II algorithm, these are: (1) moisture at the exit of the rotary dryer, (2) heat released to the environment through the dryer and (3) operating costs of the production process in the Paraguayan company. The proposed algorithm optimized operating conditions of the drying process and results are compared to the real process in the factory. Experimental results prove the ability of the proposed algorithm to decrease the moisture content of pozzolana by $28 \%$, the heat released to the environment by $38 \%$ and the operating costs by $52 \%$.
\end{abstract}

Keywords: rotary dryer, multi-objective optimization, pozzolana, evolutionary computation.

\section{Introduction}

This work aims to improve the operating parameters of the rotary dryer of the National Cement Industry of Paraguay ${ }^{1}$, in order to reduce operating costs, moisture content in the pozzolana at the exit of the rotary dryer and the emission of heat to the environment from the dryer.

In a traditional single-objective environment, i.e. when it is possible to combine the objectives to be optimized in a single objective function subject to several constraints, the optimization problem can be reduced to the search of a maximum or minimum that would be the solution of the problem when satisfying all the considered constraints. 
On the other hand, when the various objectives need to be considered simultaneously, and these objectives are conflicting with each other due to the existence of compromise relationships, there is not always a single solution to the problem, but rather a set of compromised solutions [1]. This formulation considering several simultaneous objective functions is known as a Multi-objective Optimization Problem (MOP) [2].

Several works have already studied the problem of correctly operating a rotary dryer. Douglas et al. [3] carried out a transient simulation of a rotary dryer that processes sugar crystals and obtained dynamic responses of the humidity and temperature profiles for the process, having as input a step function for both cases.

The design and operation of convective dryers, which include rotary dryers, was studied by Kiranoudis et al. [4], evaluating the operational parameters of each dryer in terms of the total annual cost.

Lobato et al. [5] used multi-objective optimization techniques of the Firefly Algorithm (FA) type for the estimation of parameters for the drying kinetics, and calculating the heat loss coefficients for a pilot plant of a rotary dryer that processes superphosphates.

Later, Alvarez [6] analyzed the optimal design of the principal physical parameters of a rotary dryer that processes pozzolana, improving the reduction in the moisture content of pozzolana by a percentage of up to $6 \%$. Thus, the production capacity of an industrial cement plant was improved. Considering another perspective, Miranda [7] improved the production capacity of a Bolivian industrial cement plant, through the use of a Design Expert software, minimizing heat loss with the environment of the pozzolana rotary dryer and minimizing the moisture content of the pozzolana.

The multi-objective optimization of a countercurrent rotary dryer for drying simple superphosphate fertilizers was proposed by Silveira et al. [8], This work proposed Multi-objective Optimization Differential Evolution (MODE) algorithms and a robust model to obtained the best operating conditions of the dryer, minimizing heat loss by the walls of the rotary dryer as well as the moisture content at the end of the length of the dryer, considering the determination of the initial temperature of the air at the inlet of the dryer, as well as the air speed and the mass flow of the solids.

Shene et al. [9] modeled and simulated a direct current rotary dryer that processes fish and soybeans; using a distributed model, they obtained the temperature profile of the drying air and the temperature profile of the treated solids, also comparing them with the experimental data obtained in a pilot plant.

Bhaskar et al. [10] compiled different researches in multi-objective optimization with application to processes involving chemical industries, as shown in Table 1:

Table 1: Multi-objective optimization in Chemical Engineering [10].

\begin{tabular}{|l|c|}
\hline \multicolumn{1}{|c|}{ Description } & Author \\
\hline Multicriteria optimization in Chemical Engineering. & {$[11]$} \\
\hline Optimal processes in synthesis systems. & {$[12]$} \\
\hline Design of a multi-stage evaporator. & {$[13]$} \\
\hline Tank aeration for water treatment. & {$[14]$} \\
\hline Optimal synthesis in metanation processes. & {$[15]$} \\
\hline Toluene-Vapor processes in desalkylation processes. & {$[16]$} \\
\hline Modelling of petrochemical industries. & {$[17]$} \\
\hline Process design with dynamic aspects. & {$[18]$} \\
\hline Chemical complexes. & {$[19]$} \\
\hline Multivariable controller module. & {$[20]$} \\
\hline Synthesis in binary distillation. & {$[21][22]$} \\
\hline Reactor-Separator-Recycle System. & {$[21][22]$} \\
\hline
\end{tabular}


Table 2 shows a summary prepared by Rangaiah and Petriciolet [23] of the main Research areas on Multi-Objective Optimization (MOO) in Chemical Engineering and the number of scientific papers published in different periods.

\begin{tabular}{|c|c|l|c|}
\hline Period & $\begin{array}{c}\text { Number of papers in } \\
\text { journals }\end{array}$ & \multicolumn{1}{|c|}{$\begin{array}{c}\text { Main application } \\
\text { areas }\end{array}$} & Reference \\
\hline Before the year 2000 & 30 & $\begin{array}{l}\text { Process design and } \\
\text { control, engineering of } \\
\text { chemical reactions, } \\
\text { Biochemical } \\
\text { engineering, water } \\
\text { treatment and control } \\
\text { of pollution, } \\
\text { electro-chemicals } \\
\text { processes. }\end{array}$ & [10] \\
\hline $\begin{array}{c}\text { From year 2000 to the } \\
\text { middle of year 2007 }\end{array}$ & 100 & $\begin{array}{l}\text { Process design and } \\
\text { operation, refinery of oil } \\
\text { and petrochemicals, } \\
\text { biotechnology and } \\
\text { technology of food, } \\
\text { pharmaceutical and } \\
\text { polymerization. }\end{array}$ & [24] \\
\hline $\begin{array}{c}\text { From year 2007 to the } \\
\text { middle of year 2012 }\end{array}$ & 230 & $\begin{array}{l}\text { Process design and } \\
\text { operation, refinery of } \\
\text { petroleum, } \\
\text { petrochemical, } \\
\text { polymerization, power } \\
\text { generation, pollution } \\
\text { control, renewable } \\
\text { energy, hydrogen } \\
\text { production, fuel cells. }\end{array}$ & [23] \\
\hline
\end{tabular}

Taking into account the previous works above mentioned, this work considers for the first time the simultaneous minimization of three objective functions in the drying of pozzolana with a rotary dryer, in a purely multi-objective context. Indeed, using a MOEA (Multi-objective Optimization Evolutionary Algorithm) this proposal simultaneously optimizes: (1) the moisture at the exit of the rotary dryer, (2) the heat transferred to the environment by the dryer and (3) the operating costs in the pozzolana drying process.

In the following section, the Multi-objective Optimization Problem is briefly presented; then, in Section 3 the mathematical model of the direct current rotary dryer is described. The methodology used for modeling a steady state direct current rotary dryer is described in Section 4. Experimental results are summarized, establishing a comparison with the real process in a Paraguayan company in Section 5 . Finally, conclusions are left for Section 6.

\section{Multi-objective optimization problem}

Formally, a multi-objective optimization problem refers to the simultaneous optimization (minimization or maximization) of two or more objective functions, where the objectives could conflict with each other [9]. The optimization problem is stated as follows:

$$
\text { Optimize } F(x)=\left[f_{1}(x), f_{2}(x), \ldots, f_{n}(x)\right]
$$

Subject to:

$$
\begin{array}{ll}
g_{i}(x) \leq 0 & i=1,2, \ldots, n_{i} \\
h_{i}(x)=0 & i=1,2, \ldots, n_{e} \\
x_{l} \leq x \leq x_{u} &
\end{array}
$$


where $n$ represents the number of objective functions to be optimized simultaneously, $x$ is a vector of $m$ decision variables (continuous or discrete) with limit values; lower $\left(x_{i}\right)$ and upper $\left(x_{u}\right)$, while $n_{i}$ and $n_{e}$ are the number of constraints in the form of inequations $(g)$ and equalities $(h)$ respectively.

The feasible space, $\Omega$ is a set of vectors $x$ that satisfy all constraints. The image of the vectors $x \in \Omega$ creates the objective space symbolized by $\Lambda$ [10].

\section{Pareto dominance:}

A vector $\mathbf{A}=\left(a_{1}, \ldots, a_{n}\right) \in \Lambda$ is said to dominate another vector $\mathbf{B}=\left(b_{1}, \ldots, b_{n}\right) \in \Lambda$ if and only if $\mathbf{A}$ is not worse than $\mathbf{B}$ in any objective function ant it is strictly better in at least one objective function. In this case, it is said that $\mathbf{A}$ dominates it $\mathbf{B}$ (A is better than $\mathbf{B})$ [11].

A vector $x^{*} \in \Omega$ in the feasible region is Pareto optimal [9, 12], if there is no other feasible vector $\mathrm{x} \in \Omega$ that dominates it, i.e., it is not possible improving any objective without deteriorating any other objective. Pareto optimal solutions are also called non-dominated solutions. The set of non-dominated solutions in $\Omega$ is known as the Pareto set (P) and its image in the objective space $\Lambda$ is called the Pareto Front (FP).

\section{Mathematical modeling of direct current drying}

The following considerations are established to present the steady model of the direct current rotary dryer $[3,12]$ :

- the dryer and burner are considered to operate practically in a steady state;

- no physical property varies with position in the control volume;

- enthalpy is considered practically independent of pressure;

- it is considered that the combustion reaction of the biofuel is complete in the burner;

- for the calculation of the heat transferred by the dryer to the surroundings, only the convective term is considered, neglecting the contributions of heat conduction and radiation.

The diagram of the process to be studied is shown in Figure 1, where it can be seen that the drying process unit consists of two units; a burner and a rotary dryer. Biofuel enters the burner together with humid air in direct current, combustion takes place and the combustion gases that leave the burner enter the rotary dryer accompanied by the humid pozzolana in direct current. In this unit the drying takes place, dry pozzolana and exhaust gases are discharged from the rotary dryer.

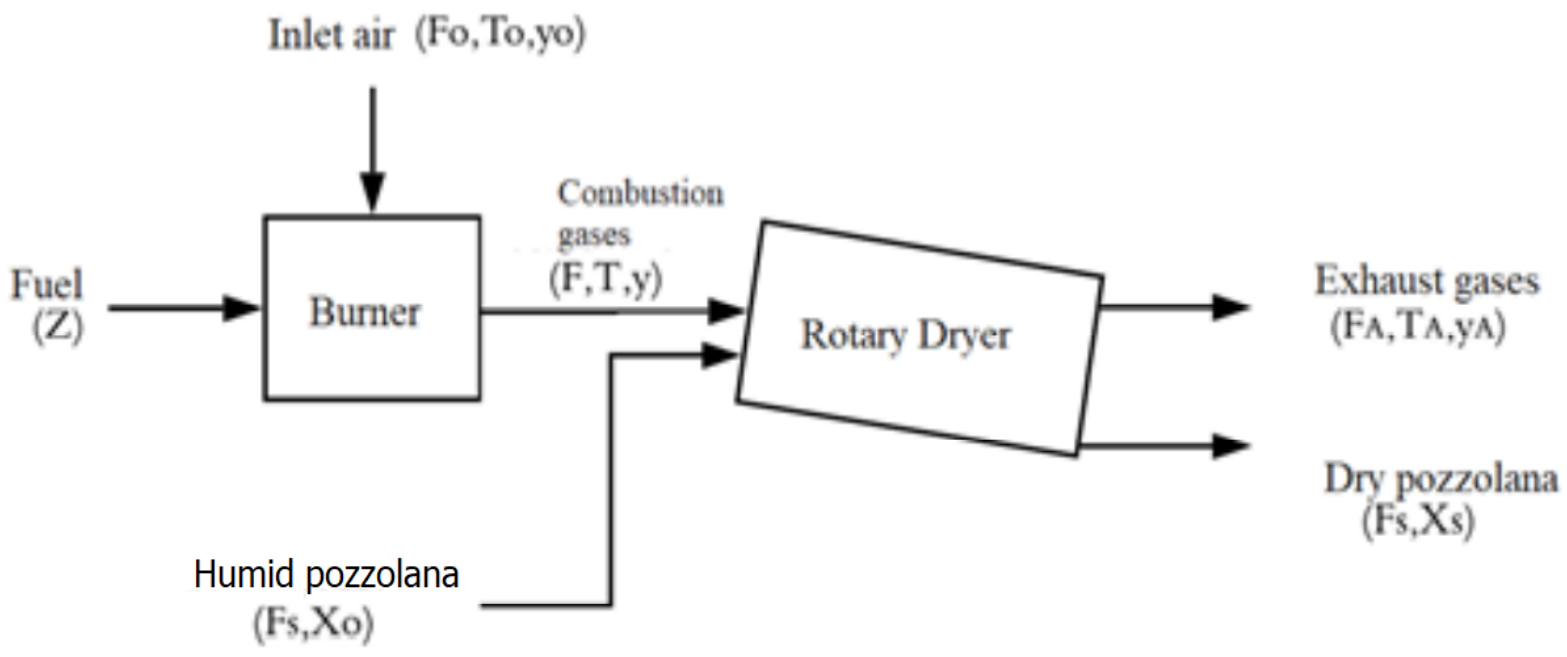

Figure 1: Diagram of the dryer and burner of the drying process unit. 


\section{Notation:}

$Z$ : Mass flow of fuel in $\mathrm{kg} / \mathrm{s}$.

$F_{o}$ : Mass flow of the air entering the burner in $\mathrm{kg} / \mathrm{s}$.

$y_{0}$ : Absolute humidity of the air entering the burner in $\mathrm{kg} / \mathrm{kg}$ dry air.

$T_{o}$ : Air temperature at the entrance of the burner in ${ }^{\circ} \mathrm{C}$.

$F$ : Mass flow rate of the combustion gases at the burner outlet in $\mathrm{kg} / \mathrm{s}$.

$T$ : Temperature of combustion gases at the exit of the burner in ${ }^{\circ} \mathrm{C}$.

$y$ : Absolute humidity of the combustion gases at the entrance of the rotary dryer in $\mathrm{kg} / \mathrm{kg}$ dry air.

$F_{s}$ : Mass flow of the solid pozzolana in the dryer in $\mathrm{kg} / \mathrm{s}$.

$X_{o}$ : Moisture of pozzolana at the entrance of the rotary dryer in $\mathrm{kg} / \mathrm{s}$.

$F_{a}$ : Mass flow of the exhaust gases of the dryer in $\mathrm{kg} / \mathrm{s}$.

$T_{a}$ : Temperature of the exhaust gases in ${ }^{\circ} \mathrm{C}$.

$X_{s}$ : Moisture of the pozzolana at the exit of the rotary dryer in $\mathrm{kg} / \mathrm{kg}$.

\subsection{Objectives of direct current multi-objective optimization}

The multi-objective problem of the direct current rotary dryer studied in this work aims to minimize: (1) the moisture at the exit of the dryer, (2) the heat that the dryer gives off to the environment and (3) the operating costs as summarized below.

\subsubsection{Moisture of the pozzolana at the outlet of the dryer $\left(f_{1}\right)$}

The moisture of the pozzolana at the outlet of the dryer must be minimal so that the grinding operation (operation that follows drying in a cement plant) is not hindered. The mass balance in the burner is detailed below, assuming that the fuel used is a biofuel, a hydrocarbon with a heat of combustion equal to $\Delta H_{f}[\mathrm{~kJ} / \mathrm{kg}]$, a hydrogen fraction $C_{H}[\mathrm{~kg} / \mathrm{kg}]$ and that the chemical reaction of combustion is [12]:

$$
\begin{gathered}
\mathrm{C}+\mathrm{O}_{2} \rightarrow \mathrm{CO}_{2} \\
\mathrm{H}_{2}+2 \mathrm{O}_{2} \rightarrow \mathrm{H}_{2} \mathrm{O}
\end{gathered}
$$

Then, $9 C_{H}[\mathrm{~kg}]$ of water vapor are produced per $[\mathrm{kg}]$ of fuel [12], that is:

$$
R_{w}=9 C_{H} Z
$$

where:

$R_{w}$ : Water production rate, $[\mathrm{kg} / \mathrm{s}]$.

The total mass and water balance on the burner is obtained by applying the following relationships [3], [12]:

$$
\begin{gathered}
F(1+y)=F_{o}\left(1+y_{o}\right)+Z \\
F y=F_{o} y_{o}+R_{w}
\end{gathered}
$$

where:

$F$ : Mass flow rate of the combustion gases at the burner outlet, [kg/s].

$F_{o}$ : Mass flow of the air entering the burner, $[\mathrm{kg} / \mathrm{s}]$.

$y$ : Absolute humidity of the combustion gases at the rotary dryer inlet, [kg/kg dry air].

$y_{0}$ : Absolute humidity of the air entering the burner, [kg/kg dry air].

$Z$ : Mass flow of fuel, [kg/s].

Combustion gases are assumed to have the same physical properties as air, therefore the energy balance in the burner remains as [12]:

$$
F(1+y) C p_{a}\left(T-T_{o}\right)=Z \Delta H_{f}
$$

where:

$C p_{a}:$ Specific heat of the combustion gases, $[\mathrm{kJ} / \mathrm{kg} \mathrm{C}]$.

$\Delta H_{f}$ : Heat of combustion, [kJ/kg].

$T$ : Inlet temperature of the combustion gases to the dryer, $\left[{ }^{\circ} \mathrm{C}\right]$.

To: Ambient temperature, $\left[{ }^{\circ} \mathrm{C}\right]$.

Applying a total mass balance in the rotary dryer, the following mathematical relationship is obtained 
for the output moisture of the pozzolana [3], [12]:

$$
f_{1}=X_{o}-\mathrm{F} / \mathrm{Fs}\left(y_{a}-y\right)
$$

where:

$f_{1}$ : Pozzolana moisture at the outlet of the rotary dryer, $[\mathrm{kg} / \mathrm{kg}]$.

$F_{s}$ : Solid pozzolana mass flow rate in rotary dryer, $[\mathrm{kg} / \mathrm{s}]$.

$X_{o}$ : Pozzolana moisture in the dryer inlet, $[\mathrm{kg} / \mathrm{kg}]$.

$y_{a}$ : Absolute moisture of the combustion gases at the outlet of the rotary dryer, [kg/kg dry air ].

\subsubsection{Heat transferred by the rotary dryer to the environment $\left(f_{2}\right)$}

The heat transferred by the rotary dryer to the environment must be minimized due to three reasons: (1) to optimize the heat transferred by the fuel for the drying of pozzolana, (2) to reduce the thermal impact to the environment, (3) to improve the operating parameters, considering that these are independent variables of the problem posed. The heat lost by the rotary dryer is mainly due to convective mechanisms, and is given by the following mathematical relationship [2]:

$$
f_{2}=K F^{m} \pi D L\left(T-T_{o}\right)
$$

where:

D: Diameter of the dryer, [m].

f2: Heat transferred by the rotary dryer to the environment, [w].

K: Experimentally obtained process constant, $\left[\mathrm{W} / \mathrm{m}^{2}{ }^{\circ} \mathrm{C}\right]$.

L: Length of the dryer, [m].

$\mathrm{m}$ : dimensionless constant of the drying process.

\subsubsection{Operating costs $\left(f_{3}\right)$}

The operating costs considered in this work include the cost of the electric energy consumed by the rotary dryer and the cost of the fuel, which is the biofuel used in the burner. Other costs such as the salaries of civil servants who operate in the drying sector are not considered as variables. An important factor is the cost of electrical energy in its tariff structure [1]. There is a price difference, called a differentiated rate, which for this study is considered as follows:

- cheap rate $\left(C_{e} f\right)$ : from o:0o $\mathrm{h}$ to 17:00 $\mathrm{h}$, and from 22:00 $\mathrm{h}$ to 23:59 $\mathrm{h}$, called off-peak hours;

- expensive rate $\left(C_{e} p\right)$ : from 17:00 $\mathrm{h}$ to 22:00 $\mathrm{h}$, called peak load hours. The operating cost is determined by the following equation [1], [3], [12]:

$$
f_{3}=q N_{i} D(M+W) C_{e i} t_{o p} b i+Z C_{z i} t_{o p} b i
$$

where:

$C_{e} i$ : Cost of electrical energy in the i-th interval, [US $\left.\$ / \mathrm{kWh}\right]$.

$\mathrm{C}_{z} i$ : Unit cost of fuel, [US\$ $/ \mathrm{kWh}$ ].

$\mathrm{f}_{3}$ : Total operating cost, [US\$].

M: Mass of pozzolana in the rotary dryer, [kg].

$\mathrm{Ni}$ : Angular velocity in the i-th interval, [rpm].

q: dimensionless coefficient for the operating cost function.

$t_{o p}$ : Operating time, [s].

$\mathrm{W}$ : Rotary dryer mass, [kg]. 


\subsection{Mathematical formulation of the problem}

Minimize $\boldsymbol{y}=\boldsymbol{f}(\boldsymbol{x})=\left[f_{1}(x), f_{2}(x), f_{3}(x)\right]^{T}$

where:

$$
\mathbf{y} \in R^{3} ; \quad \mathbf{x}=\left[x_{1} ; x_{2} ; x_{3} ; x_{4}\right],
$$

$\mathbf{x} \in R^{4}$, is the vector of the independent variables, also called manipulable variables.

$x_{1}=N \in R$, which is the angular velocity in rpm;

$x_{2}=T \in R$, which is the temperature of the combustion gases at the inlet of the rotary dryer in ${ }^{\circ} \mathrm{C}$;

$x_{3}=Z \in R$, which is the mass flow of fuel at the burner inlet, in $\mathrm{kg} / \mathrm{s}$;

$x_{4}=F_{o} \in R$, which is the mass flow of air at the burner inlet in $\mathrm{kg} / \mathrm{s}$.

subject to: $\quad x_{l} \leq x \leq x_{u}$

As an example, we can consider the following lower and upper limits:

$x_{l}=[1 ; 600 ; 0.1 ; 10]$ and $x_{u}=[10 ; 900 ; 1 ; 1000]$ according to [8], [25] and [27].

\section{Methodology}

The steady model attempts to determine the set of Pareto optimal solutions $\mathrm{P}$, minimizing the objective function $\mathbf{y}=\mathbf{f}(\mathbf{x}) \in \Lambda$ and considering as known the ambient temperature and the desired variation in the demand for pozzolana, without considering that these variables may eventually vary, in which case it would be necessary to run the optimization algorithm again.

The evolutionary algorithm selected to solve the above presented problem is the NSGA-II [13], given its well-known advantages $[1,2]$ in different engineering applications. Experimental results presented in what follows was obtained with a NSGA-II specially adapted to solve the rotary dryer problem in steady state, with a number of generations equal to 400 and a population size equal to 200 .

The Matlab R2020a software was used in a computer with an AMD E1-200 CPU processor with Radeon (TM) DD Graphics, $1000 \mathrm{MHz}$ with 2 logic processors and 4 GB of RAM memory.

The following values of the genetic operators used in the experiment are the default ones in Matlab R2020a: selection $=2$, crossing $=1$, migration (leading direction, fraction $=0,2$, interval $=20$ ), without function of hybridization and with a constraint-dependent mutation function.

\section{Results}

After 254 experimental iterations of the NSGA-II algorithm, 18 chromosomes were obtained that turned out to be the final Pareto optimal solutions, for an ambient temperature of $25{ }^{\circ} \mathrm{C}$ and a pozzolana demand of $5000 \mathrm{~kg} / \mathrm{h}$. The data of the drying process in steady state considered to perform calculations using the NSGA-II algorithm is presented in Table 3. 
Table 3: Data of the steady-state drying process

\begin{tabular}{|c|c|c|}
\hline Parameter & Value & Reference \\
\hline $\mathrm{D}(\mathrm{m})$ & 2 & {$[25]$} \\
\hline $\mathrm{L}(\mathrm{m})$ & 15 & {$[25]$} \\
\hline $\mathrm{U}\left(\mathrm{W} / \mathrm{m}^{2 \circ} \mathrm{C}\right)$ & 28,36 & {$[26]$} \\
\hline $\mathrm{T}_{\mathrm{o}}\left({ }^{\circ} \mathrm{C}\right)$ & 25 & {$[25]$} \\
\hline $\mathrm{q}$ & 1 & {$[27]$} \\
\hline $\mathrm{Ce}(\mathrm{US} \$ / \mathrm{W})$ & $7 \times 10^{-5}$ & [27] \\
\hline $\mathrm{Cz}(\mathrm{US} \$ / \mathrm{W})$ & $5 \times 10^{-5}$ & {$[27]$} \\
\hline $\mathrm{M}(\mathrm{kg})$ & 1000 & {$[25]$} \\
\hline W (kg) & 10000 & {$[25]$} \\
\hline $\mathrm{C}_{\mathrm{H}}(\mathrm{kg} / \mathrm{kg})$ & 0,106 & {$[27]$} \\
\hline$\Delta \mathrm{H}_{\mathrm{f}}(\mathrm{kJ} / \mathrm{kg})$ & $15 \times 10^{6}$ & {$[27]$} \\
\hline $\mathrm{Cp}_{\mathrm{a}}\left(\mathrm{kJ} / \mathrm{kg}^{\circ} \mathrm{C}\right)$ & 1180 & {$[27]$} \\
\hline $\mathrm{y}_{\mathrm{o}}(\mathrm{kg} / \mathrm{kg}$ de aire seco) & 0,01 & {$[25]$} \\
\hline$X_{\mathrm{o}}(\mathrm{kg} / \mathrm{kg})$ & 1 & {$[25]$} \\
\hline$\Delta \mathrm{H}_{\mathrm{V}}(\mathrm{kJ} / \mathrm{kg})$ & $2,5 \times 10^{6}$ & {$[27]$} \\
\hline $\mathrm{F}_{\mathrm{S}}(\mathrm{kg} / \mathrm{s})$ & 1,38 & {$[25]$} \\
\hline
\end{tabular}

Table 4 shows the calculated results of the decision variables and the corresponding objective functions for the problem of drying pozzolana in direct current at steady state using the already presented data. 
Table 4: Calculated results of the steady-state multi-objective optimization

\begin{tabular}{|c|c|c|c|c|c|c|c|}
\hline \multicolumn{2}{|c|}{ Chromosomes } & \multicolumn{3}{|c|}{ Decision variables } & \multicolumn{3}{|c|}{ Objective functions } \\
\hline & $x_{1}[\mathrm{rpm}]$ & $x_{2}\left[{ }^{\circ} \mathrm{C}\right]$ & $x_{3}[\mathrm{~kg}$ & $x_{4}[\mathrm{~kg} / \mathrm{s}]$ & $f_{1}[\mathrm{~kg} /$ & $f_{2}[w]$ & $f_{3}[\mathrm{U}$ \\
\hline 1 & 1.00 & 600.00 & [S] & 10.000 & & $1.539^{*} 10^{\wedge}$ & S\$] \\
\hline & & & $\begin{array}{c}0.10 \\
2\end{array}$ & & 4.473 & 6 & 1663 \\
\hline 2 & $3 \cdot 31$ & 600.00 & 0.820 & 10.008 & 1.375 & $1.539^{*} 10^{\wedge} 6$ & 5506 \\
\hline 3 & 1.55 & 600.00 & 0.472 & 10.005 & 2.879 & $1.539 * 10^{\wedge} 6$ & 2582 \\
\hline 4 & 1.90 & 600.00 & 0.620 & 10.006 & 2.238 & $1.539 * 10^{\wedge} 6$ & 3167 \\
\hline 5 & 1.00 & 600.00 & 0.602 & 10.000 & 2.316 & $1.539 * 10^{\wedge} 6$ & 1671 \\
\hline 6 & $5 \cdot 44$ & 600.00 & 0.931 & 10.023 & 0.903 & $1.539 * 10^{\wedge} 6$ & 9058 \\
\hline 7 & 1.11 & 600.05 & 0.999 & 10.006 & 0.599 & $1.539 * 10^{\wedge} 6$ & 1849 \\
\hline 8 & 1.04 & 600.00 & 0.192 & 10.000 & 4.085 & $1.539^{*} 10^{\wedge} 6$ & 1724 \\
\hline 9 & 6.25 & 600.00 & 0.973 & 10.057 & 0.734 & $1.539^{*} 10^{\wedge} 6$ & $\begin{array}{l}1039 \\
2\end{array}$ \\
\hline $\begin{array}{l}1 \\
0\end{array}$ & 1.45 & 600.00 & 0.418 & 10.001 & 3.108 & $1.539 * 10^{\wedge} 6$ & 2411 \\
\hline $\begin{array}{l}1 \\
1\end{array}$ & 4.19 & 600.00 & 0.815 & 10.012 & 1.400 & $1.539 * 10^{\wedge} 6$ & 6964 \\
\hline $\begin{array}{l}1 \\
2\end{array}$ & 3.94 & 600.00 & 0.890 & 10.018 & 1.075 & $1.539^{*} 10^{\wedge} 6$ & 6545 \\
\hline $\begin{array}{l}1 \\
3\end{array}$ & 1.00 & 600.00 & 0.102 & 10.000 & 4.473 & $1.539^{*} 10^{\wedge} 6$ & 1663 \\
\hline $\begin{array}{l}1 \\
4\end{array}$ & 6.32 & 600.00 & 0.999 & 10.066 & 0.622 & $1.539^{*} 10^{\wedge} 6$ & 10514 \\
\hline $\begin{array}{l}1 \\
5\end{array}$ & 2.40 & 600.00 & 0.605 & 10.015 & 2.308 & $1.539^{*} 10^{\wedge} 6$ & 4001 \\
\hline $\begin{array}{l}1 \\
6\end{array}$ & 1.07 & 601.81 & 0.755 & 10.091 & 1.699 & $1.544^{*} 10^{\wedge} 6$ & 1774 \\
\hline $\begin{array}{l}1 \\
7\end{array}$ & 4.54 & 600.00 & 0.786 & 10.018 & 1.525 & $1.539 * 10^{\wedge} 6$ & 7543 \\
\hline $\begin{array}{l}1 \\
8\end{array}$ & 1.04 & 600.00 & 0.345 & 10.000 & 3.423 & $1.539^{*} 10^{\wedge} 6$ & 1727 \\
\hline
\end{tabular}

In Figure 2, the values of the objective functions are shown in parallel coordinates; two trends can be seen in it; one of them exemplified by Chromosome-16 that maximizes the objective function f2; and the remaining 17 chromosomes that minimize the objective function f2 of which Chromosome-10 is chosen as the representative one to establish a comparison. The algorithm takes around 1 minute and 11 seconds to run completely. 


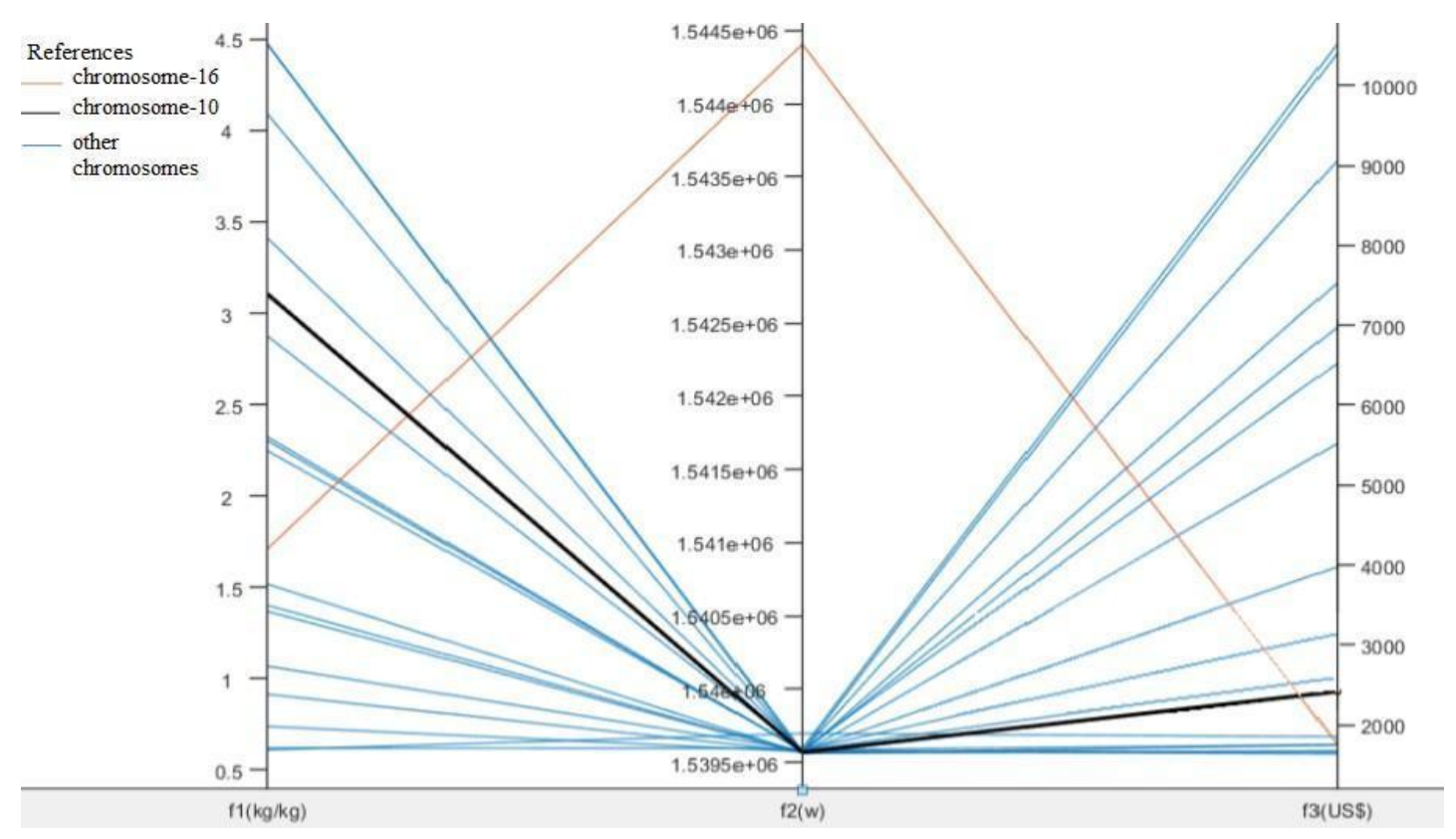

Figure 2: Results of multi-objective optimization in parallel coordinates.

When comparing the real industrial process carried out in the factory and the optimized process, it is observed that Chromosome-16 manages to improve all the three objectives with respect to the real operation, reducing the moisture of the pozzolana by $28 \%$, the heat transferred to the environment by $38 \%$ and operating costs by $52 \%$. In contrast, Chromosome-10 manages to reduce the heat transferred by $38 \%$, the operating cost by $34 \%$, but provides moisture $32 \%$ higher than the real process.

It is clear from Table 3 that the solution given by chromosome- 16 strongly dominates the real solution implemented in the Paraguayan company when the proposed optimization methodology is not used, proving the advantage of using the optimization method presented in this work.

Table 5 summarizes the comparison between the real industrial process of the Paraguayan company and 2 chromosomes: Chromosome-10 and Chromosome-16, which are representatives of the trends seen in Figure 2. The value of the operating parameters when performing several consecutive runs with the same input data and the same parameters for the algorithms are as follows: the rotary dryer angular speed has an average of $1.60 \mathrm{rpm}$ with a standard deviation of $0.60 \mathrm{rpm}$. The temperature of the inlet gases has an average value of $600.56{ }^{\circ} \mathrm{C}$ with a standard deviation of $1.28{ }^{\circ} \mathrm{C}$, the mass flow of the fuel to the burner has an average of $0.697 \mathrm{~kg} / \mathrm{s}$ with a standard deviation of $0.313 \mathrm{~kg} / \mathrm{s}$. Finally, the mass flow rate of the air entering the burner has an average equal to $10.057 \mathrm{~kg} / \mathrm{s}$ with a standard deviation of 0.083 $\mathrm{kg} / \mathrm{s}$. 
Table 5: Comparison of the real process with the optimized process

\begin{tabular}{|c|c|c|c|}
\hline & \multirow[t]{2}{*}{$\begin{array}{l}\text { real } \\
\text { process }\end{array}$} & \multicolumn{2}{|c|}{ Optimized process } \\
\hline & & $\begin{array}{c}\text { (chromoso } \\
\text { me-10) }\end{array}$ & $\underset{6)}{(\text { chromosome-1 }}$ \\
\hline$f_{1}(\mathrm{~kg} / \mathrm{kg})$ & 2.36 & 3.11 & 1.69 \\
\hline$f_{2}(w)$ & $2.47^{*} 10^{\wedge} 6$ & $1.545^{*} 10^{\wedge} 6$ & $1.540^{*} 10^{\wedge} 6$ \\
\hline$f_{3}(U S \$)$ & 3659 & 2411 & 1774 \\
\hline$x_{1}(r p m)$ & 2.20 & 1.45 & 1.07 \\
\hline$x_{2}\left({ }^{\circ} \mathrm{C}\right)$ & 950 & 600 & 601.81 \\
\hline$x_{3}(\mathrm{~kg} / \mathrm{s})$ & 0.900 & 0.418 & 0.755 \\
\hline$x_{4}(\mathrm{~kg} / \mathrm{s})$ & 21.29 & 10.00 & 10.09 \\
\hline
\end{tabular}

\section{Conclusions}

It was possible to determine the optimal operating parameters of a direct current rotary dryer that processes pozzolana in steady state using a specialized variant of the NSGA-II evolutionary algorithm, especially design to solve the formulated multi-objective problem. By using the calculated operating conditions, it was possible to minimize all three objective functions: humidity at the exit of the rotary dryer, heat transferred to the environment and operating costs, with respect to the real industrial operation in a Paraguayan company.

For future work, it is proposed that the problem of pozzolana drying should be solved following the same multi-objective context but in a semi-dynamic or purely dynamic context, where variations in non-controllable variables such as ambient temperature and the demand for pozzolana must be taken into consideration at any time.

The multi-objective optimization techniques presented in this work could be useful not only in the pozzolana drying process but also in the clinker mill unit and in the dust collection system within the National Cement Industry, a work to be analyzed in a near future.

The savings in money for the INC, applying this algorithm in the pozzolana dryer, could be around 5,5 million dollars per year (quoted on 01/21/2020); therefore, action should be taken to improve the production efficiency.

\section{Acknowledgments}

To the postgraduate program POSG 16-02 "Master in Chemical Engineering with an emphasis on Chemical Processes" of the School of Chemical Sciences of the National University of Asuncion, with financial support of CONACYT - PARAGUAY.

To the PRONII program of CONACYT - PARAGUAY. 


\section{References}

[1] B. Barán, C. von Lücken, and A. Sotelo, "Multi-objective pump scheduling optimization using evolutionary strategies," Advances in Engineering Software, vol. 36, no. 1, pp. 39-47, 2005. DOI: https://doi.org/10.1016/j.advengsoft.2004.03.012

[2] C. V. Lücken, B. Barán, and A. Sotelo, "Pump Scheduling Optimization Using Asynchronous Parallel Evolutionary Algorithms," CLEI Electronic Journal, vol. 7, no. 2, 2004. DOI: https://doi.org/10.19153/cleiej.7.2.2

[3] P. Douglas, A. Kwade, P. Lee, and S. Mallick,"Simulation Of A Rotary Dryer For Sugar Crystalline," Drying Technology, vol. 11, no. 1, pp. 129-155, 1993. DOI: https://doi.org/10.1080/07373939308916806

[4] C. T. Kiranoudis, Z. B. Maroulis, and D. Marinos-Kouris, "Design and operation of convective industrial dryers," AIChE Journal, vol. 42, no. 11, pp. 3030-3040, 1996. DOI: https://doi.org/10.1002/aic.690421105

[5] F. S. Lobato, E. B. Arruda, A. A. Cavalini, and V. Steffen, "Engineering System Design Using Firefly Algorithm and Multi-Objective Optimization," Volume 2: 31st Computers and Information in Engineering Conference, Parts A and B, 2011. DOI: https://doi.org/10.1115/DETC2011-47197

[6] R. Alvarez, "Diseño de un secador de puzolana para molienda de cemento," Huancayo, Perú: Universidad Nacional del Centro de Perú, 2014.

[7] A. Miranda, "Estudio y mejora del proceso de secado de puzolana en planta VIACHA-SOBOCE S.A.". La Paz, Bolivia: Universidad Mayor de San Andrés, 2016.

[8] G. S. Silveira, T. A. Barbosa, F. S. Lobato and E. B. Arruda, "Otimização robusta aplicada ao projeto de sistemas de engenharia. " Brazilian Journal of Development, 6(10), pp. 80410-80429, 2020. DOI: https://doi.org/10.34117/bjdv6n10-457

[9] C. Shene, F. Cuhillos, R. Perez, and P. Alvarez, "Modelling and Simulation of a Direct Contact Rotary Dryer," Drying Technology, vol. 14, no. 10, pp. 2419-2433, 1996. DOI: https://doi.org/10.1080/07373939608917214

[10] V. Bhaskar, S. K. Gupta and A. K. Ray, "Applications of multiobjective optimization in chemical engineering. " Reviews in chemical engineering, 16(1), pp. 1-54, 2000. DOI: https://doi.org/10.1515/REVCE.2000.16.1.1

[11] J. H. Seinfeld and W. L. MacBride, "Optimization with multiple performance criteria." Ind. Eng. Chem., Proc. Des. Dev., pp. 53-57, 1970. DOI: https://doi.org/10.1021/i260033a010

[12] N. Nishida, A. Ichikawa and E. Tazki, "Synthesis of optimal process systems with uncertainty." Ind. Eng. Chem., Proc. Des. Dev., pp. 209-214, 1974. DOI: https://doi.org/10.1021/i260051a003

[13] H. Nishitani and E. Kunugita, "The optimal flow pattern of multiple effect evaporator systems." Comput. Chem. Eng., pp. 261-268, 1979. DOI: https://doi.org/10.1016/0098-1354(79)80044-7

[14] N. Nishida, G. Stephanopoulos and A. W. Westerberg, "A review of process synthesis. " AIChE Journal, 27(3), pp. 321-351, 1981. DOI: https://doi.org/10.1002/aic.690270302

[15] J. H. Shieh and L. T. Fan, "Multiobjective optimal synthesis of methanation process." 73rd annual meeting of AIChE, Chicago, IL, Nov. 1980.

[16] T. Umeda, T. Kuriyama, S. Kobayashi and A. Ichikawa, "Interactive solution to multiple criteria problems in chemical engineering design." Comput. Chem. Eng., 4, pp. 157- 165, 1980. DOI: https://doi.org/10.1016/0098-1354(80)87002-5

[17] A. Sophos, E. Rotstein and G. Stephanopoulos, "Multiobjective analysis in modeling the petrochemical industry." Chem. Eng. Sci., 35, pp. 2415-2426, 1980. DOI: https://doi.org/10.1016/0009-2509(80)85054-8

[18] A. M. Lenhoff and M. Morari, "Design of resilient processing plants--I. Process design under consideration of dynamic aspects." Chem. Eng. Sci., 37, pp. 245-258, 1982. DOI: https://doi.org/10.1016/0009-2509(82)80159-0 
[19] I. E. Grossmann, R. Drabbant and R. K. Jain, "Incorporating toxicology in the synthesis of industrial chemical complexes." Chem. Eng. Commun., 17, pp. 151-170, 1982. DOI: https://doi.org/10.1080/00986448208911622

[20] T. A. Meadowcraft, C. Brosilow and G. Stephanopoulos, "The modular multivariable controller: 1. Steady-state properties." AIChE J., 38, pp. 1254-1277, 1992. DOI: https://doi.org/10.1002/aic.690380812

[21] M. L. Luyben and C. A. Floudas. "Analyzing the interaction of design and control--1. A multiobjective framework and application to binary distillation synthesis." Comput. Chem. Eng., 18, pp. 933-969, 1994. DOI: https://doi.org/10.1016/0098-1354(94)E0013-D

[22] M. L. Luyben and C. A. Floudas, "Analyzing the interaction of design and control--2. ReactorSeparator-Recycle system.” Comput. Chem. Eng., pp. 971-994, 1994. DOI: https://doi.org/10.1016/0098-1354(94)85006-2

[23] G. P. Rangaiah and A.B. Petriciolet, "Multi-objective optimization in chemical engineering: developments and applications.” John Wiley \& Sons, 2013. DOI: 10.1002/9781118341704

[24] M. Masuduzzaman and G. P. Rangaiah, "Multi-objective optimization applications in chemical engineering. " Multi-Objective Optimization: Techniques and Applications in Chemical Engineering, pp. 27-59, 2009.

[25] C. Oviedo, "Optimización Multiobjetivo de un secador rotatorio utilizando algoritmos evolutivos". Master Thesis of Chemical Engineering, National University of Asuncion - Paraguay, 2021.

[26] F. P. Incropera, D. P. DeWitt, T. L. Bergman and A. Lavine, "Principles of Heat and Mass Transfer. " John Wiley \& Sons, 2013.

[27] A. S. Mujumdar, "Handbook of industrial drying," New York: Dekker, 1995. DOI: https://doi.org/10.1201/9781420017618 